\title{
PENGARUH DIVIDEND INITIATIONS DAN DIVIDEND CUT/OMISSIONS TERHADAP RETURN SAHAM DI BURSA EFEK JAKARTA
}

\author{
Sri Dwi Ari Ambarwati \\ Fakultas Ekonomi \\ Universitas Pembangunan Nasional "Veteran" Yogyakarta
}

\begin{abstract}
This research investigates market reactions to initiations and cut/omissions of cash dividend payment. Consistent with prior literature, the result of this research tend to support the propositions that shareholders make considerable use of the information implicit in dividend announcement. Shareholders react positively significant to the dividend initiations announcement and negatively significant to the dividend cut/omissions announcement. $A$ multiple regression model is formulated to identify the factors that contribute significantly to the capital gain (Ioss) suffered by shareholders when firm decide to initiate (cut/omit) dividend. Result indicate that, in conformity with the information content hypothesis, the shareholders's respond to dividend initiations significantly depends on the firm size and the cumulative return movement (CARM) in the preceding period. Whereas, the shareholders's respond to dividend cut/omissions significantly depends on the cumulative return movement (CARM) in the preceding period and risk/corrected beta of the firm at alpha $1 \%$ and $5 \%$.
\end{abstract}

Keywords: Signaling hypothesis, Dividend initiations, dividend cut/omissions

PENDAHULUAN

Investor yang menginvestasikan dananya di pasar modal bertujuan untuk memperoleh imbalan atau pendapatan dari dana yang diinvestasikan tersebut baik berupa dividen atau capital gain. Dividen merupakan bagian keuntungan perusahaan yang dibagikan kepada para pemegang saham sedangkan capital gain merupakan bagian keuntungan perusahaan yang akan ditahan untuk reinvestasi (Husnan:1994). Sehingga perubahan kebijakan dividen sekecil apapun dianggap mampu mempengaruhi reaksi investor dan akhirnya dapat mempengaruhi harga saham. Isu yang terkait dengan perubahan kebijakan dividen tersebut adalah information content of dividend hypothesis yang menyatakan bahwa pengumuman dividen mengandung informasi yang mampu mempengaruhi reaksi pasar.

Perusahaan melakukan perubahan kebijakan dividen dengan berbagai alasan, misalnya kebijakan pembayaran dividen pertama kali setelah beberapa tahun tidak membayar dividen (dividend initiations) dilakukan untuk memberi informasi bagi investor akan prospek laba perusahaan yang lebih baik untuk saat ini dan di masa depan. Sedangkan kebijakan memotong ataupun menghapus pembayaran dividen (dividend cut/omissions) dilakukan perusahaan karena perusahaan membutuhkan dana untuk 
membiayai pertumbuhan. Oleh karena itu jika pengumuman perubahan kebijakan dividen yang tidak diantisipasi ini merupakan petunjuk bagi pasar mengenai perubahan laba yang diperoleh perusahaan maka sinyal atau kandungan informasi ini dapat memicu pergerakan harga saham naik atau turun.

Salah satu pendekatan yang digunakan untuk menguji kandungan informasi adalah dengan mengamati pergerakan harga saham disekitar pengumuman perubahan pembayaran dividen yang tidak diharapkan melalui event study. Dari berbagai penelitian dapat diketahui bahwa pengaruh pengumuman perubahan kebijakan dividen terhadap harga saham belum menemukan pendapat atau kesimpulan yang seragam. Oleh karena itu penulis tertarik untuk melakukan penelitian lebih lanjut untuk mempertegas konfirmasi dari observasi-observasi yang mengungkap bahwa peningkatan (penurunan) dan inisiasi (omisi) dividen secara signifikan akan diikuti oleh peningkatan (penurunan) harga saham.

Alasan mengapa diperlukan penelitian lebih lanjut, karena dengan semakin banyak bukti empiris mengenai pengaruh pengumuman perubahan dividen terhadap harga saham akan lebih mempertegas dan memperkuat validitas mengenai hipotesis informational content of dividend (Aharony \& Dotan:1994)

\section{TUJUAN PENELITIAN}

Melakukan pengujian empiris guna mengetahui pengaruh pengumuman dividend initiations dan dividend cut/omissions terhadap return saham di Bursa Efek Jakarta serta menguji apakah reaksi pasar tersebut dipengaruhi oleh variabel-variabel spesifik perusahaan.

\section{LANDASAN TEORI DAN PENGEMBANGAN HIPOTESIS}

Ada beberapa teori yang dapat digunakan oleh perusahaan untuk menerangkan bahwa dividen yang dibayarkan digunakan sebagai isyarat mengenai prospek return di masa yang akan datang. Dalam penelitian ini digunakan dividend signaling theory sebagai kerangka teorinya karena teori ini relevan dengan tujuan penelitian yaitu untuk membuktikan bahwa pengumuman perubahan pembayaran dividen mengandung informasi.

Dividend signaling theory berdasarkan pada asumsi bahwa dividen diperlukan untuk memberikan informasi positif dari manajer yang mempunyai nformasi lengkap tentang kondisi perusahaan yang sesungguhnya kepada investor yang miskin akan informasi tentang kondisi perusahaan sesungguhnya. Fenomena seperti ini terjadi karena adanya asymmetric information antara manajer dengan investor. (Ross,1977; Bhattacarya,1979; Miller \& Rock,1985 dan John \& William,1985) 
Pengumuman dividen sebagai alat untuk mengirimkan isyarat yang nyata kepada pasar mengenai hasil kerja perusahaan di masa kini dan di masa yang akan datang adalah merupakan cara yang tepat meskipun mahal tetapi sangat berarti. Setelah menerima isyarat melalui pengumuman dividen maka pasar akan bereaksi terhadap pengumuman perubahan dividen yang akan dibayarkan sehingga bisa dikatakan pasar menangkap informasi tentang prospek perusahaan yang terkandung dalam pengumuman tersebut.

Pendapat umum dalam literatur keuangan baik empiris maupun teoritis menyatakan bahwa pada umumnya, dividend initiations memiliki positive impact on firm value. Beberapa peneliti berpendapat bahwa pengumuman inisiasi secara tak terantisipasi memberikan optimistic signal mengenai kinerja perusahaan di masa depan. Asquith \& Mullins (1983) secara konseptual menyatakan bahwa abnormal return yang dihubungkan dengan inisiasi dividen dapat dibagi menjadi dua komponen, a yield effect dan an initiations effect. Efek inisiasi merefleksikan nilai yang dihasilkan dari pembayaran dividen periode berikutnya dan didapatkannya manfaat dengan adanya program inisiasi dividen. The yield effect meliputi perubahan nilai yang dihasilkan dari besarnya initial dividend dan menangkap information content atas pembayaran dividen tersebut.

Sedangkan reaksi pasar terhadap dividend cut/ omissions secara umum negatif karena pemotongan dan penghapusan dividen dianggap sebagai bad news oleh investor. Beberapa peneliti seperti Michaely, et.al (1995), Ghosh \& Wolridge $(1988,1991)$ menemukan bukti empiris bahwa pemotongan dan penghapusan dividen direspon negatif oleh pasar dan besarnya reaksi tersebut lebih besar dibanding reaksi pasar terhadap peningkatan dividen. Alasan yang diajukan terhadap fenomena ini adalah karena pengurangan dividen dianggap lebih banyak mengandung informasi (Michaely, et.al :1995).

Healy dan Palepu (1988) mempelajari 131 perusahaan yang melakukan dividend initiations dan 172 perusahaan yang melakukan dividend ommisions di NYSE. Mereka menggunakan market model untuk menghitung abnormal return 60 hari sebelum dan 20 hari sesudah pengumuman. Rata-rata return pada hari -1 dan 0 untuk perusahaan yang membayar dividen pertama kalinya adalah 3,9\% (positif signifikan pada alpha 1\%). Sedangkan rata-rata return dua hari untuk perusahaan yang menghapus dividen pertama kalinya adalah -9,5\% (negatif signifikan padaalpha 1\%).

Ghosh \& Wolridge (1988) melakukan penelitian mengenai reaksi pasar terhadap dividend cut/omissions serta menggunakan model regresi berganda untuk mengetahui pengaruh variabel seperti persentase perubahan dividen, ukuran perusahaan, kinerja saham sebelumnya, risiko, pengumuman simultan earning dan stock dividen yang dikeluarkan serentak 
dengan pengumuman dividen. Menemukan bukti empiris bahwa pasar bereaksi negatif terhadap pengumuman dividen cut/omissions dan dipengaruhi oleh ukuran perusahaan, persentase perubahan dividen serta kinerja saham sebelum pengumuman.

Michaely, et.al (1995) mendukung hasil Healy dan Palepu (1988). Menggunakan data perusahaan NYSE/AMEX selama 1964-1988 sebagai sample perusahaan yang melakukan dividend initiations dan omissions. Abnormal return dihitung dengan menggunakan buy and hold strategy. Mereka menemukan hasil empiris bahwa pasar bereaksi secara negatif terhadap dividend omissions yang ditunjukkan dengan harga saham perusahaan yang bersangkutan menyimpang menurun (drift down) dan positif terhadap dividend initiations ditunjukkan penyimpangan harga saham ke atas (drift up). Besarnya reaksi pasar untuk dividend omissions adalah dua kali dari reaksi pasar untuk dividend initiations.

Zhenhu Jin (2000) menemukan bukti empiris yang agak berbeda dengan peneliti lainnya yaitu bahwa terdapat $64.9 \%$ perusahaan bereaksi positif dan $35.2 \%$ perusahaan bereaksi negatif terhadap pengumuman inisiasi dividen. Hal ini membuktikan adanya dividend signaling dimana inisiasi dividen dapat dinilai positif oleh pasar, namun disisi lain inisiasi dividen juga dapat dinilai negatif karena diasumsikan oleh investor sebagai sinyal kurangnya peluang untuk investasi. Setelah dilakukan pengujian terhadap variabel karakteristik khusus perusahaan seperti size, Institutional Holding, Board Ownership, Q-Ratio, Dividend Yield, Pre-CAR, Earning Volatility, dan Earning Change dengan analisis regresi berganda ditemukan bahwa size dan dividend yield signifikan untuk perusahaan yang bereaksi positif terhadap inisiasi.

Penelitian mengenai perubahan kebijakan dividen khususnya dividend cut/ omissions juga pernah dilakukan di Bursa Efek Jakarta. Caecilia (2002) dan Fatmawati (1999) menguji reaksi pemegang saham terhadap pengumuman dividend omissions/cut di BEJ, dan menemukan hasil bahwa pasar bereaksi negatif signifikan terhadap pengumuman dividend omissions/cut.

Berdasarkan pada tinjauan teoritis dan pada hasil temuan empiris di atas maka penulis tertarik untuk membuktikan lebih lanjut pengaruh pengumuman perubahan dividen dalam hal ini dividend initiations dan dividend cut/omissions terhadap return saham di Bursa Efek Jakarta dengan mengacu metode penelitian Michaely,et.al (1995) dan Zhenhu Jin (2000) ,dengan mengajukan hipotesis;

$\mathbf{H}_{1}$ : Pemegang saham bereaksi positif terhadap pengumuman pembayaran dividen pertama kalinya (dividend initiations) di Bursa Efek Jakarta. 
$\mathrm{H}_{2}$ : Pemegang saham bereaksi negatif terhadap pengumuman pemotongan ataupun penghapusan dividen pertama kalinya (dividend cut/ omissions) di Bursa Efek Jakarta.

Reaksi pemegang saham dalam penelitian ini diproksi dengan $a b-$ normal return yang dihitung dari selisih actual return dengan expected return. Expected return diestimasi dengan market model seperti yang dilakukan oleh Zenhu Jin (2000).

Oleh karena dalam hal ini reaksi pemegang saham diproksikan dengan abnormal return maka selanjutnya abnormal return diteliti keterkaitannya dengan variabel-variabel karakteristik spesifik dengan mengacu pada metode penelitian Ghosh \& Woolridge (1988) dan Zhenhu Jin (2000). Adapun variabel-variabel karakteristik khusus perusahaan tersebut adalah sebagai berikut:

a. Perubahan Dividend Yield (DivYld)

Menurut Zhenhu Jin (2000) dan Michaely,et.al (1995) jika pengumuman tidak terantisipasi maka argumen dari teori signaling dan agency cost mengimplikasikan bahwa abnormal return pada saat pengumuman dividen berhubungan secara positif atau searah dengan perubahan dividend yield.

$\mathrm{H}_{3} \mathrm{a}$ : Perubahan Dividen yield berpengaruh positif terhadap abnormal return

b. Ukuran perusahaan (Size)

Menurut penelitian Zhegal (1983), Eddy dan Sheifert (1988) (dalam penelitian Zhenhu Jin:2000) mengatakan size merupakan proksi yang baik untuk tingkat publisitas informasi yang tersedia mengenai suatu perusahaan. Mereka mendapatkan bukti empiris bahwa reaksi pemegang saham terhadap pengumuman pembayaran kenaikan dividen adalah lebih besar untuk perusahaan kecil.

$\mathrm{H}_{3} \mathbf{b}$ : Size perusahaan berpengaruh negatif terhadap abnormal return.

c. CARM (Cumulative Return Movement)

Ghosh dan Woolridge (1988) menggunakan cumulative return movement sedangkan Zenhu Jin (2000) menggunakan Pre-CAR selama periode estimasi untuk mengukur fluktuasi tingkat keuntungan dan menemukan bukti bahwa variabel CARM memiliki hubungan yang searah dengan abnormal return.

$\mathrm{H}_{3} \mathrm{C}:$ CARM berpengaruh positif terhadap abnormal return

d. Institutional holdings (Inst),

Menurut Zhenhu (2000) kepemilikan institusional yang besar akan lebih mengetahui informasi mengenai perusahaan dan mengurangi manfaat dari pengumuman informasi selanjutnya. 
$\mathrm{H}_{3} \mathrm{~d}$ : Besarnya persentase Institusional holding berpengaruh negatif terhadap abnormal return

e. Beta Saham

Eades (1982) membuktikan secara empiris bahwa reaksi pasar terhadap perubahan dividen yang tidak diharapkan merupakan fungsi positif dari risiko perusahaan. Hal ini berarti bahwa semakin besar risiko perusahaan semakin besar pula reaksi pemegang saham. Adapun berta yang digunakan adalah beta yang sudah dikoreksi dengan metode Fowler dan Rorke (1983).

$\mathrm{H}_{3} \mathrm{e}$ : Beta saham berpengaruh positif terhadap abnormal return

f. Growth (Market to Book Value)

Menurut Zhenhu (2000) proksi peluang pertumbuhan perusahaan di masa depan yang digunakan adalah rasio Tobin's Q. Dalam penelitian ini peluang pertumbuhan diproksi dengan market to book value dari ekuitas. FCF hypothesis memprediksi reaksi harga saham lebih besar untuk perusahaan dengan tingkat pertumbuhan rendah (Patricia:2000). $\mathrm{H}_{3} \mathrm{f}:$ Growth berpengaruh negatif terhadap abnormal return

\section{METODE PENELITIAN}

\section{Sampel penelitian}

Penentuan sampel adalah dengan purposive sampling method (Cooper dan Emory:1995). Sampel yang dipilih adalah semua perusahaan yang melakukan inisiasi dan omisi dividen mulai tahun 1989-2000 dengan kriteria:

a. Kriteria pemilihan sampel perusahaan yang membayar dividen pertama kalinya (dividend initiations) adalah sebagai berikut (Michaely, et.al:1995):

1) Dividend initiations adalah pembayaran dividen tunai pertama kalinya setelah minimal dua kali berturut-turut tidak membayar dividen tunai selama 1989-2000.

2) Perusahaan tersebut sudah harus terdaftar di BEJ selama satu tahun sebelum membayar dividen tunai pertama kalinya .

3) Perusahaan tersebut membayar dividen tunai setahun sekali.

4) Tidak ada peristiwa penting selama periode pengamatan misal stock splits, right issue, merjer, akuisisi atau restrukturisasi.

5) Tidak ada pengumuman lain seperti pengumuman laba dalam lima hari sebelum inisiasi.

b. Kriteria pemilihan sampel perusahaan yang menghapus dividen pertama kalinya (dividend omissions) atau memotong dividen (dividend cut) adalah sebagai berikut: 
1) Perusahaan tersebut harus sudah terdaftar di BEJ selama dua tahun atau lebih dan biasanya membayar dividen tunai secara rutin dalam jumlah tetap, meningkat dan menurun namun periode 1989-1996 melakukan penghapusan atau pemotongan dividen pertama kalinya.

2) Perusahaan tersebut paling tidak telah dua kali membayar dividen kas tahunan kemudian tidak membayar atau memotong dividen tunai pada tahun berikutnya (hanya dua tahun berturut-turut karena alasan ketersediaan sampel di BEJ).

\section{Cara Pengumpulan Data}

Sumber data dalam penelitian ini dapat diperoleh dari Indonesian Capital Market Directory, Fact Book, JSX Statistic, database yang didownload dari PPA, MM UGM dan database BEJ melalui internet www.jsX.co.id. Berdasarkan kriteria pemilihan sampel di atas, perusahaan yang memenuhi syarat kelengkapan data yaitu 33 perusahaan yang melakukan inisiasi dividen, 36 perusahaan yang melakukan pemotongan dan 24 perusahaan yang melakukan penghapusan dividen.

\section{Penentuan Periode Peristiwa dan Periode Estimasi}

Tanggal yang dianggap sebagai event pengumuman dividend initiations dan dividend cut/ omissions adalah tanggal pelaksanaan RUPS yang dilaporkan ke BEJ dan sudah dipilih rapat yang tidak membahas stock splits, right issue dan divestasi, dan tanggal ini ditetapkan sebagai $t_{0}$.

Berdasarkan tanggal RUPS tersebut kemudian ditentukan kisaran 10 hari sebelum $(\mathrm{t}-10)$ dan 10 hari sesudah $(\mathrm{t}+10)$ sebagai event period sehingga event period ada 21 hari. Periode estimasi yang digunakan untuk mengestimasi expected return saham dalam penelitian ini adalah 100 hari sejak t-110 sampai t-11.( Jogiyanto, 1998).

\section{Teknik Analisis Data dan Pengujian Hipotesis}

Tahap pertama penelitian ini adalah menguji hipotesis pertama dan kedua yaitu pemegang saham bereaksi terhadap pengumuman dividend initiations dan dividend omissions/cut. Model yang digunakan untuk menghitung abnormal return saham dalam penelitian ini adalah market model.

Alasan menggunakan market model karena model ini akan memberikan nilai expected return yang lebih halus karena digunakannya teknik regresi OLS antara return actual dengan market return pada periode estimasi. Berdasarkan metode ini abnormal return dapat dihitung melalui beberapa tahapan dalam event study sebagai berikut: 
1) Menghitung Return saham harian $\left(R_{i t}\right)$ individual selama hari pengamatan:

$$
R_{i t}=\frac{P_{i t}-P_{i t-1}}{P_{i t-1}}
$$

Keterangan:

$\mathrm{R}_{\mathrm{it}}=$ Return saham harian saham i pada hari $\mathrm{t}$

$P_{i t}=$ Harga saham harian saham i hari ke $t$

$\mathrm{P}_{\mathrm{it}-1}=$ Harga saham masing-masing perusahaan pada hari ke t-1

2) Menghitung Return Pasar harian sealama periode pengamatan dengan rumus:

$$
R_{m t}=\frac{I H S G_{i t}-I H S G_{i t-1}}{I H S G_{i t-1}}
$$

Keterangan:

$\mathrm{R}_{\mathrm{mt}}=$ Return pasar harian pada hari $\mathrm{t}$

$\mathrm{IHSG}_{\mathrm{t}}=$ Indeks Harga Saham Gabungan pada hari t

$\mathrm{IHSG}_{\mathrm{t}-1}=$ Indeks Harga Saham Gabungan pada hari t-1

3) Menghitung $\alpha$ dan $\beta$ untuk tiap-tiap saham dengan meregresikan return harian saham terhadap market return harian selama periode estimasi. Karena beta tersebut mengandung bias maka harus disesuaikan (Hartono dan Surianto: 1999). Adapun koreksi beta yang digunakan adalah metode Fowler dan Rorke (1983) dengan periode koreksi yang cukup panjang dengan rumus:

$$
\begin{aligned}
& R_{i, t}=\alpha_{1}+\beta_{1}^{-4} R_{m t-4}+\beta_{1}^{-3} R_{m t-3}+\beta_{1}^{-2} R_{m t-2}+\beta_{1}^{-1} R_{m t-1}+\beta_{1}{ }^{0} R_{m t} \\
& +\beta_{1}+1 R_{m t+1}+\beta_{1}+2 R_{m t+2}+\beta_{1}+3 R_{m t+3}+\beta_{1}{ }^{+4} R_{m t+4}+\varepsilon_{l, t}
\end{aligned}
$$

Koefisien beta perusahaan i $\left(\beta_{1}\right)$ yang telah dikoreksi dengan metode koreksi Fowler dan Rorke (1983) empat lead dan empat lag dapat dihitung dengan rumus:

$$
\begin{aligned}
\beta_{1}= & W_{4} \beta_{1}^{-4}+W_{3} \beta_{1}^{-3}+W_{2} \beta_{1}^{-2}+W_{1} \beta_{1}^{-1}+\beta_{1}^{0}+W_{1} \beta_{1}{ }^{+1}+W_{2} \beta_{1}{ }^{+2}+W_{3} \beta_{1}^{+3} \\
& +W_{4} \beta_{1}{ }^{+4}
\end{aligned}
$$

Bobot (W) yang dipakai untuk mengoreksi bias beta saham digunakan untuk mengalikan koefisien-koefisien regresi untuk empat lead dan empat lag dan dapat dihitung dengan rumus:

$$
\begin{aligned}
& W_{1}=\frac{1+2 p 1+2 p 2+2 p 3+p 4}{1+2 p 1+2 p 2+2 p 3+2 p 4} \\
& W_{1}=\frac{1+2 p 1+2 p 2+p 3+p 4}{1+2 p 1+2 p 2+2 p 3+2 p 4} \\
& W_{1}=\frac{1+2 p 1+p 2+p 3+p 4}{1+2 p 1+2 p 2+2 p 3+2 p 4}
\end{aligned}
$$


$W_{1}=\frac{1+p_{1}+2 p 2+p_{3}+p_{4}}{1+2 p_{1}+2 p_{2}+2 p_{3}+2 p_{4}}$

Sedangkan $\rho_{1}, \rho_{2}, \rho_{3}, \rho_{4}$ diperoleh dari persamaan regresi sebagai berikut:

$R_{m t}=\alpha_{l}+\rho_{1} R_{m t-1}+\rho_{2} R_{m t-2}+\rho_{3} R_{m t-3}+\rho_{4} R_{m t-4}+\varepsilon_{t}$

4) Menghitung expected return setiap saham selama periode pengamatan berdasarkan nilai $\alpha$ dan $\beta$ yang sudah dikoreksi tersebut menggunakan teknik single index market model :

$E\left(R_{i, t}\right)=\alpha_{i}+\beta_{i} R_{m, t}+\varepsilon_{i, t}$ Keterangan:

$E\left(R_{i, t}\right)=$ expected return saham i pada hari $t$

$\alpha_{1} \quad=$ intercept saham i

$\beta_{\mathrm{i}} \quad=$ slope /risiko saham i

$\mathrm{R}_{\mathrm{m}, \mathrm{t}} \quad=$ market return pada hari $\mathrm{t}$

$\varepsilon_{i, t} \quad=$ residual variance saham i pada hari $\mathrm{t}$

5) Menghitung abnormal return tiap saham selama periode peristiwa dengan rumus:

$A R_{i, t}=R_{i, t}-E\left(R_{i, t}\right)$

Keterangan:

$A R_{i, t} \quad=a b n o r m a l$ return saham i pada hari t

$\mathrm{R}_{\mathrm{i}, \mathrm{t}} \quad=$ actual return saham i pada hari $\mathrm{t}$

$E\left(R_{i, t}\right)=$ expected return saham i pada hari $t$

6) Menghitung Average Abnormal Return setiap hari selama periode peristiwa:

$A A R_{t}=\sum A R_{i t} / k$

Keterangan:

AARt =rata-rata abnormal return pada hari ke-t

ARi,t $=$ abnormal return saham i pada hari $t$

$\mathrm{K} \quad=$ jumlah saham yang terpengaruh oleh pengumuman

7) Melakukan pengujian statistik (t-test) terhadap average abnormal return $(A A R)$ pada periode peristiwa untuk melihat signifikansi $A A R$ tersebut. $S A A R_{i, t}$ (standardized Average Abnormal Return) merupakan nilai t-hitung untuk $A A R$ pada hari ke-t selama periode peristiwa (Jogiyanto:1998).

a. Menghitung KSE dengan rumus:

$$
K S E_{i}=\sqrt{\frac{\sum\left(R_{i, t}-E\left(R_{i, t}\right)\right)^{2}}{T-2}}
$$

Keterangan:

KSEi =kesalahan standar estimasi saham $\mathrm{i}$

$\mathrm{R}_{\mathrm{i}, \mathrm{t}} \quad=$ actual return saham $\mathrm{i}$ 
$\mathrm{E}\left(\mathrm{R}_{\mathrm{i}, \mathrm{t}}\right)=$ expected return saham $\mathrm{i}$

$\mathrm{T}-2$ = Jumlah hari di periode estimasi

b. Menentukan Standardized Average Abnormal Return (SAAR = thitung) selama periode peristiwa dan dianggap sebagai t-hitung untuk AAR dengan rumus:

$$
S A A R_{t}=\frac{1}{\sqrt{k}} \sum \frac{A R_{i t}}{K S E_{i t}}
$$

Keterangan:

$\mathrm{SAAR}_{\mathrm{t}}=$ standardized average abnormal return saham pada hari $\mathrm{t}$ di periode peristiwa

$\mathrm{AR}_{\text {it }} \quad=$ abnormal return saham i pada hari $\mathrm{t}$

$\mathrm{KSE}_{\text {it }}=$ kesalahan standar estimasi saham i pada hari ke $\mathrm{t}$ di periode peristiwa

8) Menghitung Cumulative Abnormal Return (CAR) yang merupakan penjumlahan abnormal return mulai hari awal periode jendela sampai hari ke-t:

$C A R_{i, t}=\sum A R_{i, t}$

9) Menghitung Cumulative Average Abnormal Return (CAARt) selama periode peristiwa $\left(\mathrm{t}_{-10}\right.$ sampai $\left.\mathrm{t}_{+10}\right)$

$C A A R_{i, t}=\sum A A R_{t}$

Keterangan:

$C A A R_{i, t}=$ Cumulative Average Abnormal Return saham i hari ke $\mathrm{t}$

$A A R_{t} \quad=$ Average Abnormal Return saham i hari ke $t$

$\mathrm{t} \quad=$ hari pada periode peristiwa

10) Menentukan standardized cumulative average abnormal return (SCAAR) dengan rumus:

$$
\operatorname{SCAAR}_{n}=\frac{1}{\sqrt{\mathrm{a}}} \sum_{t=-10}^{n} S A R_{i, t}
$$

Keterangan:

$\mathrm{SCAAR}_{\mathrm{n}}=$ standardized cumulative average abnormal return

$\mathrm{SAR}_{\mathrm{i}, \mathrm{t}}=$ standardized average abnormal return saham i pada hari $\mathrm{t}$

a $\quad=n-(-10)+1$

Tahap penelitian berikutnya adalah menguji hipotesis ketiga, yaitu menguji pengaruh variabel karakteristik khusus perusahaan terhadap anormal return (sebagai proksi reaksi pemegang saham). Pengujian ini dilakukan dengan menggunakan model Regresi berganda. Adapun model persamaan regresi ganda secara umum adalah:

$C A R_{i t}=a+b_{1} d$ DivYld $+b_{2}$ Size $+b_{3} C A R M+b_{4}$ Inst $+b_{5}$ Beta $+b_{6}$ MBVE $+e$ 
Keterangan:

CARit =Cumulative abnormal return pada hari terakhir di periode jendela untuk perusahaan ke i

DDivYl = perubahan besarnya dividend yield yang diterima diukur dengan $D_{t}-D_{t-1} / P_{-10}$

Size =In (Market Value), MV adalah harga saham penutupan pada akhir bulan sebelum tanggal pengumuman dikalikan jumlah saham yang beredar pada akhir bulan sebelum tanggal pengumuman.

CARM =Cumulative Return Movement selama periode estimasi sebagai proksi kinerja

Inst =Persentase saham yang dimiliki investor institusional dari ICMD.

Beta =risiko perusahaan diukur dengan beta saham model pasar selama periode estimasi. Beta dianggap mencerminkan kinerja saham di masa depan

$M B V E$ = peluang pertumbuhan diproksikan sebagai rasio market to book value perusahaan sebelum pengumuman dividen.

a $=$ intercept

e $\quad=$ error term

Setelah diperoleh persamaan regresi berganda maka dilakukan uji signifikansi menggunakan uji-t statistik dan apabila koefisien $b_{1}, b_{2}, b_{3}, b_{4}, b_{5}$ dan $b_{6}$ secara signifikan berbeda dari nol maka abnormal return yang diperoleh pemegang saham dipengaruhi juga oleh variabel karakteristik khusus perusahaan. Metode regresi OLS akan dapat dijadikan alat estimasi yang tidak bias jika telah memenuhi persyaratan BLUE yakni tidak terdapat autokorelasi, multikolinearitas dan heterokedastisitas sehingga uji asumsi klasik perlu dilakukan.

\section{HASIL ANALISIS}

\section{Deskripsi Beta Saham Terkoreksi}

Menurut Johnson (1996) estimasi beta dengan menggunakan model estimasi OLS pada dasarnya masih mengandung kelemahan karena dapat menimbulkan perhitungan beta yang bias. Permasalahan beta yang bias banyak terjadi pada estimasi beta saham-saham di pasar modal yang tipis (Arif \& Johnson,1990; Nassir \& Shamser,1996; Hartono \& Surianto, 1999) dan pasar modal di Indonesia yaitu Bursa Efek Jakarta termasuk pasar modal yang tipis (Suwandi,1997 dan Hartono,1998).

Hasil penelitian Hartono \& Surianto (1999) di BEJ antara tahun 1996-1997 menyatakan bahwa estimasi beta saham di BEJ merupakan beta yang masih bias sehingga estimasi beta tersebut perlu dikoreksi. Mereka menggunakan ketiga metode koreksi dan menemukan bahwa metode yang paling mampu mengurangi bias estimasi beta di pasar modal 
Indonesia yaitu BEJ adalah metode Fowler \& Rorke empat lead dan empat lag. Penelitian ini menggunakan metode yang sama.

Deskripsi hasil perhitungan beta saham individual dengan kedua metode OLS dan metode FR tersebut dapat dilihat dalam Tabel 1 dibawah ini:

Tabel 1.

\begin{tabular}{|l|c|c|c|c|}
\hline \multicolumn{1}{|c|}{ Metode } & Mean & Minimum & Maximum & $\begin{array}{c}\text { Standar } \\
\text { deviasi }\end{array}$ \\
\hline Metode OLS & 0,276600 & $-1,3670$ & 2,0340 & 0,670756 \\
\hline $\begin{array}{l}\text { Metode FR 4 lead } \\
\text { 4 lag }\end{array}$ & 0,957200 & $-3,3247$ & 8,0870 & 1,654745 \\
\hline
\end{tabular}

Dari hasil pengujian deskriptif bahwa rata-rata beta saham individual yang dihitung dengan metode OLS adalah 0,276600 dan setelah dikoreksi dengan metode Fowler dan Rorke empat lead dan empat lag menjadi 0,957200. Hasil tersebut menunjukkan bahwa metode ini mampu mengoreksi bias beta saham individual terbukti dengan rata-rata beta saham yang cenderung bergerak ke arah nilai absolut 1,00 (Blume,1975; Hartono \& Surianto,1999.

\section{Pengujian Reaksi Investor Terhadap Pengumuman Dividend Initiations}

Hasil pengujian statistik abnormal return sesudah koreksi beta dapat dilihat pada Tabel 2 .

Pada Tabel 2 disajikan secara ringkas hasil pengujian hipotesis pertama dengan menggunakan uji t di sekitar tanggal pengumuman dividend initiations. AAR positif dan signifikan pada alpha $10 \%$ muncul pada 10 hari sebelum pengumuman (t-10) dengan AAR sebesar 0.01407, sedangkan $A A R$ positif dan signifikan pada alpha $5 \%$ muncul pada saat pengumuman dividend initiations ( $\mathrm{t}-0$ ), pada 1 hari setelah pengumuman $(\mathrm{t}+1)$ dan pada 6 hari setelah pengumuman $(\mathrm{t}+6)$ dengan nilai $A A R$ sebesar 0.01528; 0.02408; dan 0.01201.

Penjelasan yang dapat dikemukakan terhadap hasil pengujian ini adalah bahwa munculnya $A A R$ yang positif dan signifikan pada saat pengumuman dividend initiations menunjukkan bahwa pemegang saham bereaksi positif terhadap pengumuman dividend initiations atau dengan kata lain hipotesis alternatif diterima. Temuan ini sama dengan hasil yang didapatkan oleh Asquit \& Mullin (1983), Heally \& Palepu (1988), Michaely, et.al (1995), Patricia, et.al (2000), Zenhu Jin (2000), Sujoko (1999) dan Rina Bukit (1999). 
Tabel 2. Hasil Pengujian Average Abnormal Return/AAR Harian di sekitar hari pengumuman dividend initiations

\begin{tabular}{|c|c|c|c|}
\hline Hari ke & $\mathrm{AAR}_{\mathrm{t}}$ & t- hitung & Keterangan \\
\hline$t-10$ & $0.01407^{\star}$ & 1.34240 & Signifikan 10\% \\
\hline$t-9$ & 0.00292 & 0.13473 & Tidak signifikan \\
\hline$t-8$ & -0.00563 & 0.30814 & Tidak signifikan \\
\hline$t-7$ & -0.00521 & -0.27623 & Tidak signifikan \\
\hline$t-6$ & -0.00657 & -0.41731 & Tidak signifikan \\
\hline$t-5$ & -0.00703 & -0.92304 & Tidak signifikan \\
\hline $\mathrm{t}-4$ & 0.00624 & 0.20541 & Tidak signifikan \\
\hline$t-3$ & -0.01549 & -1.08054 & Tidak signifikan \\
\hline$t-2$ & -0.00306 & -0.22649 & Tidak signifikan \\
\hline$t-1$ & -0.00141 & -0.06474 & Tidak signifikan \\
\hline to & $0.01528 * \star$ & 1.73339 & Signifikan 5\% \\
\hline$t+1$ & $0.02408^{\star *}$ & 2.08065 & Signifikan 5\% \\
\hline$t+2$ & 0.00155 & -0.05349 & Tidak signifikan \\
\hline$t+3$ & 0.00397 & 0.69183 & Tidak signifikan \\
\hline$t+4$ & -0.01048 & -0.46074 & Tidak signifikan \\
\hline$t+5$ & -0.00160 & -0.14336 & Tidak signifikan \\
\hline$t+6$ & $0.01201^{\star \star}$ & 2.25697 & Signifikan 5\% \\
\hline$t+7$ & -0.01270 & -0.63697 & Tidak signifikan \\
\hline$t+8$ & -0.00161 & -0.58045 & Tidak signifikan \\
\hline$t+9$ & 0.00197 & 0.09174 & Tidak signifikan \\
\hline$t+10$ & 0.01091 & 1.18363 & Tidak signifikan \\
\hline
\end{tabular}

Munculnya $A A R$ sebelum pengumuman terjadi pada 10 hari sebelum pengumuman dikeluarkan sebesar 0.01407 pada alpha 10\%. Hal ini diduga karena adanya kebocoran informasi, sebagian investor mungkin sudah memperoleh informasi dari pihak dalam perusahaan mengenai perubahan pembayaran dividen. Sedangkan munculnya $A A R$ pada $t+1$ dan $\mathrm{t}+6$ setelah pengumuman dikeluarkan diduga karena adanya distribusi informasi yang belum simetris sehingga hanya sebagian investor yang sudah mengetahui pengumuman tersebut pada waktunya dan sebagian investor lainnya terlambat mengetahui informasi tersebut.

Penjelasan lain yang dapat dikemukakan adalah munculnya $A A R$ negatif sesudah pengumuman dividend initiations pada $t+4, t+5 t+7$ dan $t+8$ mencerminkan penilaian ekonomis pasar akan dampak event tersebut bagi perusahaan yang kurang menguntungkan sehubungan dengan perubahan dividen yang tidak terlalu besar dan diduga pula karena sebagian pemegang saham sudah mengantisipasi akan terjadinya event tersebut. Temuan ini serupa dengan penemuan Zenhu Jin (2000).

Perilaku AAR di sekitar pengumuman dividend initiations dapat dilihat secara visual dari grafik yang ada pada Gambar 1. 
Gambar 1.

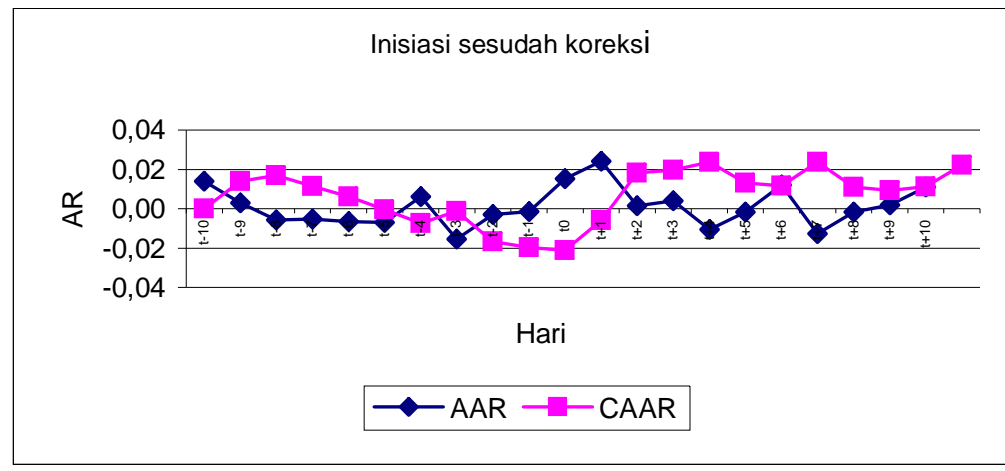

Pengujian Reaksi Investor Terhadap Pengumuman Dividend Cut/ Omissions

Berikut ini merupakan hasil pengujian statistik abnormal return sesudah koreksi beta.

Tabel 3. Hasil Pengujian Average Abnormal Return/AAR Harian di sekitar hari pengumuman dividend Cut/ Omissions

\begin{tabular}{|l|r|r|c|}
\hline Hari ke & AAR & T-hitung & Keterangan \\
\hline $\mathrm{t}-10$ & -0.00530 & 0.14677 & Tidak signifikan \\
$\mathrm{t}-9$ & 0.00422 & 0.48941 & Tidak sign \\
$\mathrm{t}-8$ & $-0.00406^{\star *}$ & -1.68686 & signifikan $5 \%$ \\
$\mathrm{t}-7$ & 0.00296 & -0.35146 & Tidak sign \\
$\mathrm{t}-6$ & 0.00236 & 0.70008 & Tidak sign \\
$\mathrm{t}-5$ & 0.00647 & 1.16027 & Tidak sign \\
$\mathrm{t}-4$ & -0.00031 & 0.77690 & Tidak sign \\
$\mathrm{t}-3$ & -0.00423 & -1.06685 & Tidak sign \\
$\mathrm{t}-2$ & -0.00219 & -0.56977 & Tidak sign \\
$\mathrm{t}-1$ & 0.00120 & 0.50823 & Tidak sign \\
$\mathrm{t} 0$ & $-0.00509 * * *$ & -2.49132 & signifikan $1 \%$ \\
$\mathrm{t}+1$ & 0.00316 & 1.21591 & Tidak sign \\
$\mathrm{t}+2$ & -0.00009 & 0.70770 & Tidak sign \\
$\mathrm{t}+3$ & $-0.01036 * \star *$ & -3.10992 & signifikan $1 \%$ \\
$\mathrm{t}+4$ & 0.00405 & 1.04879 & Tidak sign \\
$\mathrm{t}+5$ & -0.00167 & 0.22828 & Tidak sign \\
$\mathrm{t}+6$ & -0.00072 & -0.82705 & Tidak sign \\
$\mathrm{t}+7$ & 0.00249 & 1.26411 & Tidak sign \\
$\mathrm{t}+8$ & $-0.00185 * *$ & -1.98716 & Tidak sign \\
$\mathrm{t}+9$ & -0.00108 & 0.12585 & Tidak sign \\
$\mathrm{t}+10$ & 0.00180 & 1.03648 & Tidak sign \\
\hline $\mathrm{K}$ & & & \\
\hline
\end{tabular}

Keterangan: ${ }^{* *}=$ sign pada alpha $=5 \%(\mathrm{t}<-1.6711)$

$\star * \star=$ sign pada alpha $=1 \%(\mathrm{t}<-2.3912)$ 
Average Abnormal Return negatif dan signifikan pada alpha 5\% muncul pada t-8 dengan nilai $A A R$ sebesar - 0.00406 dan muncul pada hari $\mathrm{t}+8$ dengan $A A R$ sebesar -0.00185 . Sedangkan $A A R$ negatif dan signifikan pada alpha $1 \%$, muncul pada saat pengumuman ( $\mathrm{t}-0)$ dan hari $\mathrm{t}+3$ dengan nilai sebesar -0.00509 dan -0.01036 .

Penjelasan yang dapat dikemukakan adalah munculnya $A A R$ yang negatif dan signifikan pada saat pengumuman dividend Cut/ Omissions (t0) menunjukkan bahwa pemegang saham bereaksi negatif terhadap pengumuman dividend Cut/Omissions atau dengan kata lain hipotesis alternatif diterima. Reaksi pemegang saham yang negatif ini sesuai dengan teori sinyal yaitu pengumuman Dividend Initiations dan dividend Cut/Omissions cenderung diartikan sebagai sinyal negatif akan prospek kinerja perusahaan saat ini dan di masa mendatang yang semakin buruk. Temuan ini sama dengan hasil yang didapatkan oleh Asquit \& Mullin (1983), Heally \& Palepu (1988), Ghosh \& Wolridge (1988), Michaely et.al (1995), Patricia,et.al (2000), dan Caecilia (2002).

Munculnya $A A R$ sebelum pengumuman terjadi pada hari t-8 sebesar -0.00406 pada alpha $5 \%$. Hal ini diduga karena adanya kebocoran informasi yaitu sebagian investor mungkin sudah memperoleh informasi dari pihak dalam perusahaan atau karena investor sudah memperkirakan akan terjadinya penurunan dividen akibat penurunan earning sebelumnya.

Sedangkan munculnya $A A R$ pada hari $t+3$ dan hari $t+8$ yaitu sebesar -0.01036 dan -0.00185 pada alpha $1 \%$ dan $5 \%$ diduga karena adanya distribusi informasi yang belum simetris sehingga hanya sebagian investor yang sudah mengetahui pengumuman ini pada waktunya dan sebagian investor lainnya terlambat mengetahui.

Hasil ini juga menjelaskan perbedaan hasil penelitian Sucipto (1997) dan Rina Bukit (1999) yang menyatakan tidak terjadi abnormal return negatif signifikan pada saat setelah pengumuman penurunan atau penghapusan dividen yang dikeluarkan oleh BEJ karena informasi sudah diserap pertama kali pada saat pelaksanaan RUPS.

Penjelasan lain yang bisa dikemukakan sehubungan munculnya reaksi negatif yang sebagian besar tidak signifikan bahkan ada yang positif adalah bahwa porsi keuntungan yang dibagikan sebagai dividen pada Bursa Efek Jakarta relatif kecil sehingga investor mungkin tidak terlalu mengharapkan dividen sebagai sumber dananya sehingga tidak terlalu kecewa ketika dividen yang dibagikan berkurang Perilaku $A A R$ di sekitar pengumuman dividend Cut/ Omissions dapat dilihat dari grafik yang ada pada Gambar 2. 
Gambar 2.

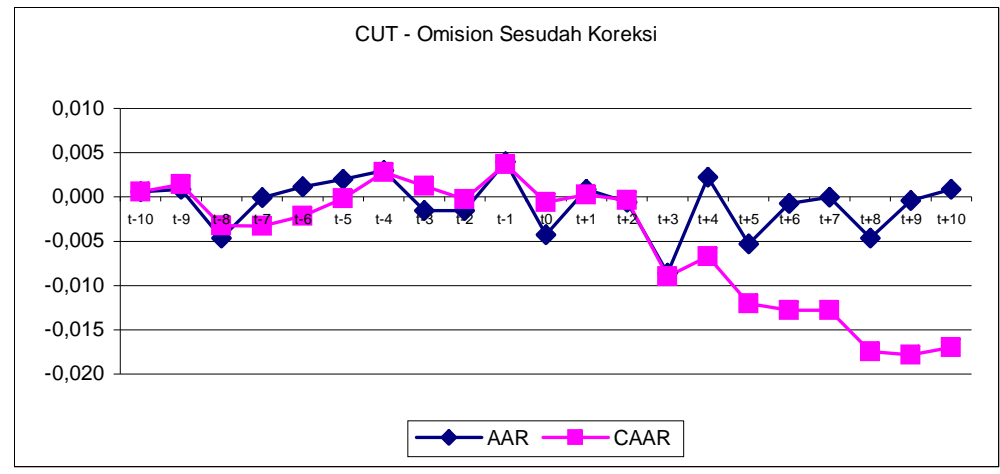

Hasil Pengujian Regresi Berganda Sampel Dividend Initiations

Hasil regresi secara ringkas dapat dilihat pada tabel berikut:

Tabel 4.Rangkuman Hasil Perhitungan Analisis Regresi Berganda

\begin{tabular}{|c|c|c|l|}
\hline Variabel & Koefisien Regresi & t-hitung & Sig-t \\
\hline (constant) & .436 & 1.899 & .069 \\
DIVYLD & .305 & .764 & .452 \\
Ln Size & $-1.915 \mathrm{E}-02$ & -2.312 & $.029^{\star *}$ \\
CARM & .213 & 3.468 & $.002^{\star \star \star}$ \\
Inst & $2.547 \mathrm{E}-02$ & .247 & .807 \\
Beta & $2.179 \mathrm{E}-02$ & 1.442 & .161 \\
MBVE & $7.523 \mathrm{E}-03$ & .934 & .359 \\
& & & \\
\hline $\mathrm{R}^{2}$ & $=0.599$ & & \\
Adjusted R2 & $=0.506$ & & \\
F & $=6.470$ & & \\
& $=0.000^{\star \star *}$ & & \\
\hline
\end{tabular}

Keterangan: * sign pada alpha $1 \%$ dan $5 \%$

Berdasarkan ringkasan hasil regresi di atas dapat diketahui bahwa model yang digunakan dapat menjelaskan $50.6 \%$ dari variasi variabel dependent. Secara keseluruhan model ini signifikan pada tingkat kepercayaan 99\% (nilai F-hitung 6.470) sehingga model ini cukup memadai untuk digunakan sebagai alat analisis.

Kesimpulan pengujian hipotesis ketiga adalah bahwa size dan fluktuasi return sebelum pengumuman (CARM) signifikan dan memiliki arah sesuai yang diprediksikan terhadap abnormal return yang diterima pemegang saham. Hal ini menunjukkan bahwa semakin kecil ukuran perusahaan dan semakin besar fluktuasi return maka kandungan informasi yang disam- 
paikan melalui pengumuman inisiasi dividen lebih direspon oleh pemegang saham secara positif. Secara parsial temuan ini mendukung hipotesis signaling theory.

Hasil Pengujian Regresi Berganda Sampel Dividend Cut/ Omissions Hasil regresi secara ringkas dapat dilihat pada tabel berikut:

Tabel 5. Rangkuman Hasil Perhitungan Analisis Regresi Berganda

\begin{tabular}{|c|c|c|l|}
\hline Variabel & Koefisien Regresi & t-hitung & Sig-t \\
\hline (constant) & .271 & .873 & .387 \\
DIVYLD & -.399 & -1.029 & .308 \\
Ln Size & $-6.055 \mathrm{E}-03$ & -.474 & .637 \\
CARM & -.267 & -6.993 & $.000^{\star \star *}$ \\
Inst & -.157 & -1.885 & .065 \\
Beta & $-2.751 \mathrm{E}-02$ & -2.382 & $.021^{\star \star}$ \\
MBVE & $-1.387 \mathrm{E}-02$ & -1.131 & .263 \\
\hline $\mathrm{R}^{2}$ & $=0.547$ & & \\
Adjusted R2 & $=0.496$ & & \\
F & $=10.668$ & & \\
& $=0.000^{\star \star *}$ & & \\
\hline Keterangan * sign pada alpha 1\% dan 5\%
\end{tabular}

Berdasarkan ringkasan hasil regresi di atas dapat diketahui bahwa model yang digunakan dapat menjelaskan $49.6 \%$ dari variasi variabel dependent. Secara keseluruhan model ini signifikan pada tingkat kepercayaan 99\% (nilai F-hitung 10,668) sehingga model ini cukup memadai untuk digunakan sebagai alat analisis.

Kesimpulan pengujian hipotesis ketiga yaitu pengaruh variabel karakteristik khusus perusahaan terhadap abnormal return investor adalah bahwa hanya variabel beta saham dan kumulatif pergerakan return (CARM) sebelum pengumuman yang negatif signifikan dan memiliki arah sesuai yang diprediksikan. Secara parsial temuan ini mendukung hipotesis signaling theory. ${ }^{*}$

\section{KESIMPULAN}

Berdasarkan hasil analisis dalam penelitian ini maka peneliti memberikan beberapa kesimpulan sebagai berikut:

1. Pengumuman dividend initiations ditanggapi positif oleh para investor di Bursa Efek Jakarta terbukti adanya abnormal return yang positif dan

${ }^{*}$ Model sudah lolos uji asumsi klasik 
signifikan pada hari pengumuman (t0) dengan tingkat kepercayaan 95\%. Hal itu mengindikasikan pengumuman dividen initiation masih direspon oleh pasar sebagai kabar baik.

2. Pengumuman dividend cut/omissions ditanggapi negatif oleh para investor di Bursa Efek Jakarta, terbukti adanya abnormal return yang negatif dan signifikan pada hari pengumuman (t0) dengan tingkat kepercayaan 99\%. Hal itu mengindikasikan pengumuman dividend cut/omissions masih direspon oleh pasar sebagai kabar buruk. Hasil ini mendukung penelitian Ghosh \& Wolridge (1988), Michaely,et.al (1995), Patricia,et.al (2000).

3. Reaksi investor juga muncul sebelum pengumuman perubahan pembayaran dividen. Hal ini diduga karena adanya kebocoran informasi dari pihak dalam perusahaan atau kemungkinan para investor sudah mengantisipasi adanya pengumuman perubahan dividen sebelumnya sehingga sudah bereaksi sebelum ada pengumuman (dari peningkatan/penurunan earning). Selain itu reaksi juga muncul beberapa hari setelah pengumuman, Hal ini diduga karena adanya penyebaran informasi yang tidak simetris sehingga hanya sebagian investor yang sudah mengetahui informasi pada saat pengumuman sedangkan yang lainnya terlambat mengetahui informasi tersebut.

4. Reaksi investor terhadap dividend initiations ternyata dipengaruhi juga oleh variabel khusus perusahaan yaitu variabel perubahan In size dan fluktuasi return (CARM). Sedangkan reaksi investor terhadap dividend cut/omissions dipengaruhi oleh CARM dan beta. Hal itu mengindikasikan bahwa besarnya reaksi investor masih dipengaruhi oleh variabelvariabel khusus yang ada pada perusahaan.

5. Model regresi kedua sampel penelitian sudah lolos uji asumsi klasik sebagai syarat pengujian regresi berganda. Sehingga kedua model regresi yang dihasilkan dapat digunakan untuk memprediksi variabel terikat dengan memberikan hasil yang lebih baik dan akurat.

\section{KETERBATASAN DAN IMPLIKASI PENELITIAN YANG AKAN DATANG}

1. Jumlah sampel yang memenuhi kriteria dividend initiations dan dividend cut/omissions masih relatif sedikit sehingga dapat menimbulkan masalah kecukupan statistikal. Penelitian yang akan datang dapat dilanjutkan seiring dengan bertambahnya usia dan jumlah sampel yang terdaftar di BEJ sehingga diperoleh hasil penelitian yang lebih baik dan signifikan.

2. Penelitian ini hanya menguji reaksi pasar dalam jangka pendek yaitu 21 hari periode peristiwa sehingga penelitian mendatang perlu mela- 
kukan pengamatan terhadap kinerja jangka panjang misalnya dua atau tiga tahun

3. Penelitian ini belum menggunakan perusahaan sebagai control group untuk lebih mempertegas apakah perubahan dividen berpengaruh terhadap return saham sehingga penelitian mendatang perlu mempertimbangkan perusahaan lain yang tidak melakukan perubahan dalam kebijakan dividennya.

4. Implikasi hasil penelitian dilihat dari hasil uji signifikansi ternyata pasar modal Indonesia sudah cukup efisien sehingga reaksi investor atas perubahan pembayaran dividen relatif kecil, kemungkinan investor sudah menganggap perubahan dividen sebagai suatu hal yang rutin atau karena perubahannya tidak cukup signifikan.

5. Implikasi lainnya adalah perlunya investor menyadari terjadinya kebocoran informasi dari pihak manajemen mengenai rencana perubahan pembayaran dividen.

6. Penelitian ini sudah memberikan bukti empiris tentang pengaruh pengumuman dividend initiations dan dividend cut/omissions terhadap keuntungan investor.

\section{DAFTAR PUSTAKA}

Aharony, J., dan Swary, (1980). "Quarterly Dividend and Earnings Announcements and stockholder' Return; An Empirical Analysis", Journal of Finance 35.

Asquit dan Mullin, (1983). "The Impact of Initiations Dividend Payment on Shareholders Wealth", Journal of Business, 259-270.

Amsari, M.I, (1993). "Pengaruh Pengumuman Dividen Terhadap Harga Saham di Pasar Modal Indonesia", Tesis S-2 UGM, Yogyakarta.

Brigham dan Gapensky, (1999), "Intermediate Financial Management, Sixth Edition, The Dryden Press Harcout Brace College Publisher.

Below dan Johnson, (1996). "An Analysis of Shareholder Reaction to Dividend Announcements in Bull and Bear Markets", Journal of Financial Strategic Decisions,15-27.

Brown dan Warner, (1985). "Using Daily Stock Returns: The Case of Event Studies", Journal of Financial Economics, 3-33.

Benartzi, et.al, (1997). "Do Changes in Dividends Signal the Future or the Past?", The Journal do Finance", 1007-1034.

Christie, W.G., (1990). "Dividend Yield and Expected Returns: The ZeroDividend Puzzle", Journal of Financial Economics, 95-125. 
Caecilia, (2002). "Analisis Reaksi Pemegang Saham terhadap Dividend Omissions/Cut di BEJ", Tesis S-2 UGM.

DeAngelo, et.al, (2000). "Special Dividend and The Evolution of Dividend Signaling", www.proquest.pqdauto.com

Fama, (1970). "Efficient Capital Market: A Review of Theory and Empirical Work:,Journal of Finance 2, 383-423.

Ghosh dan Woolridge (dalam Caecillia:2002), "An Analysis of Shareholder Reaction to Dividend Cut and Omissions", 1988, 281-294

Hartono, J., (2000). "Teori Portofolio dan Analisis Investasi", Ed. 2, BPFE, Jogjakarta.

Healy dan Palepu, (1988). "Earning Information Conveyed by Dividend Initiations and Omissions", Journal of Financial Economics, 149-175.

Han, Lee and Suk, (1999). "Institutional Shareholders and Dividends", Journal of Financial and Strategic Decisions, 53-62.

Jones, P. Charles, (2000). Investment Analysis and Management, $7^{\text {th }}$ edition, John Wiley 7 Sons.

Koch and Shenoy, "The Information Content of Dividend and Capital Structure Policies", Financial Management, 1999, 16-35

Lipson, et.al, (1998). "Dividend Initiations and Earnings Surprises", Financial Management, 36-45.

Myers and Majluf, (1984). "Corporate Financing and Investment Decisions When Firms Have Information That Investors Do Not Have", Journal of Financial Economics, 187-221.

Michaely, et.al, (1995). "Price Reactions to Dividend Initiations and Omissions: Overreaction or Drift?", The Journal Of Finance, Vol. L, No.2, 573-607.

Mitra , D. \& Owers, J., (1990). "The Information Content of Dividend Initiations in Asymetrical Information Environment", Working Paper presented at the 1990 FMA Meeting.

Nissim dan Ziv, (2000). "Dividend Changes and Future Profitability", Columbia Business School.

Patricia A.Ryan, et.al, (2000). "An Empirical Analysis of Reactions to Dividend Policy Changes for NASDAQ Firms", Journal of Financial and Strategic Decisions, Vol.1, No.13, 35-47. 
Sujoko, (1999). "Analisis Kandungan Informasi Dividen dan Ketepatan Reaksi Pasar: Pengujian terhadap Signaling Theory Studi Empiris di BEJ", Tesis S-2 UGM.

Zhenhu Jin, (2000). "On Differential Market Reaction to Dividend Initiations", The Quarterly Review of Economics and Finance, 263-277.

Watt, R., (1973). "The Information Content of Dividends, Journal of Business, 191-211. 